\title{
Helyi infiltrációs érzéstelenítés alkalmazása nagyízületi endoprotézisek beülttetése során
}

\author{
de Jonge Tamás dr. - Görgényi Szabolcs dr. \\ Szabó Gabriella dr. - Torkos Miklós Bulcsú dr. \\ Markusovszky Egyetemi Oktatókórház, Ortopédiai Sebészeti Osztály, Szombathely
}

\begin{abstract}
Bevezetés: A nagyízületi endoprotézis-beültetések jelentős posztoperatív fájdalommal járnak. A lokális infiltrációs analgesia hatékony, de költséges eljárás, hazánkban nem terjedt el széles körben. Célkitüzés: Módosított összetételú helyi infiltrációs fájdalomcsillapítással szerzett tapasztalataink bemutatása. Módszer: Primer csípő-, illetve térdízületi totális endoprotézis-beültetésen átesett 99 páciens adatait dolgoztuk fel prospektíve. Valamennyi páciens a mútét során helyi infiltrációs fájdalomcsillapításban részesült, amelyhez az ajánlásokhoz képest módosított összetételú koktélt alkalmaztunk. A posztoperatív első 18 órában óránként rögzítettük a betegek által a fájdalomskálán bejelölt fájdalomintenzitást. Feljegyeztük, hogy a betegek milyen analgetikus terápiában részesültek még posztoperatíve. Költséghatékonysági számítást is végeztünk. Kontrollcsoportként 97 teljes primer csípő-, illetve térdprotetizált páciens szolgált. Eredmények: Az infiltrációs érzéstelenítésben részesült betegek fájdalomérzete szignifikánsan alacsonyabb volt $(\mathrm{p}<0,001)$. Fájdalomcsillapító-igényük közel felére csökkent, posztoperatív fájdalomcsillapításukra $47 \%$-kal kevesebbet költöttünk. Köpetkeztetés: Nagyízületi endoprotézis beültetése során általunk alkalmazott, lényegesen olcsóbb helyi infiltrációs érzéstelenítés eredményesen csökkenti a betegek közvetlen posztoperatív fájdalomérzetét, lehetővé teszi a koraibb mobilizációt. Orv. Hetil., 2017, 158(9), 352-357.
\end{abstract}

Kulcsszavak: csípőprotézis, térdprotézis, posztoperatív fájdalom, módosított helyi infiltrációs fájdalomcsillapítás

\section{Local infiltration analgesia in total joint replacement}

Introduction: Total hip and knee replacment surgeries are characterized by severe postoperative pain. Local infiltration analgesia is proved to be very effective. However this method has not been widely used in Hungary. Aim: To evaluate the efficacy of the local infiltration analgesia with modified components in patients underwent total hip or knee replacement surgery. Method: Data of 99 consecutive patients underwent primary total hip or knee replacement surgery were evaluated prospectively. In all the 99 surgeries modified local infiltration analgesia was applied. Postoperative pain reported on a visual analog scale was recorded as well as the need for further analgetics during the first 18 hours after surgery. The cost of the analgetic drugs was calculated. The control group comprised 97 consecutive patients underwent total hip or knee replacement, where local infiltration analgesia was not applied. Statistical analysis was done. Results: Patients received local infiltration analgesia reported significantly less pain $(\mathrm{p}<0.001)$. The need for postoperatively given analgetics was almost $50 \%$ less, and the cost of all postoperative analgetics was $47 \%$ less than in the control group. Conclusion: In total hip and knee replacement surgeries the modified local infiltration analgesia decreases postoperative pain effectively and contribute to the early mobilization of the patients.

Keywords: hip replacement, knee replacement, prosthesis, postoperative pain, modified local infiltration analgesia

de Jonge, T., Görgényi, Sz., Szabó, G., Torkos, M. B. [Local infiltration analgesia in total joint replacement]. Orv. Hetil., $2017,158(9), 352-357$.

(Beérkezett: 2016. november 11.; elfogadva: 2017. január 16.)

\section{Rövidítések}

LIA = lokális infiltrációs analgesia; NFS = numerikus fájdalomskála; PCA-pumpa = betegvezérelt fájdalomcsillapító; $\mathrm{WHO}=$ Egészségügyi Világszervezet
A nagyízületi endoprotetika mára már minden ortopédiai osztály által rutinszerűen végzett beavatkozássá vált. E gyógyítómunka érdekes paradoxonja, hogy az ízületi fájdalmak megszûnéséhez egy jelentős posztoperatív fáj- 
dalmakkal járó mútéti beavatkozáson keresztül vezet az út.

A XXI. század első évtizedét a WHO a „Csont és ízület dekádjá"-nak nyilvánította. Számos újítás (minimálisan invazív technikák megjelenése, gyógyszeres vérzéscsillapítás intraoperatív bevezetése [1]) mellett az ortopédiai nagymütétek utáni hatásos fájdalomcsillapítás is kiemelt figyelmet kapott:

- Általánossá vált a spinalis subarachnoidealis érzéstelenítés alkalmazása: a közvetlen posztoperatív szakban még tart az érzéstelenítés hatása, fokozatosan tér viszsza a fájdalomérzet, van lehetőség időben a fájdalomcsillapítók adására.

- Az aneszteziológiai ajánlásoknak megfelelően kialakított protokollt vezettünk be a mütét utáni fájdalomcsillapításra. Numerikus fájdalomskálán (NFS) meghatározott fájdalomérzet alapján vagy tramadolszármazékok, vagy nalbuphin-HCl tartalmú készítmények parenteralis adagolásával igyekeztünk csökkenteni a betegek fájdalmát, az ajánlásoknak megfelelően nem szteroid típusú gyulladáscsökkentők adjuváns alkalmazásával. További kiegészítőként intravénásan adott Algopyrin szerepel még a protokollban. Sajnos ez a protokoll sem váltotta be a hozzá füzött reményeket, az ortopédiai nagymütétek utáni erôs fájdalmat így sem sikerült a kívánt mértékben csillapítani.

- Szintén aneszteziológiai ajánlások alapján, ha a beteg által bemondott fájdalomszint eléri vagy meghaladja a 6-os szintet, akkor morfin adása indikált. Annak ellenére, hogy a $2,5 \mathrm{mg}$ morphinum- $\mathrm{HCl}$ intravénás bolus adagolásával (szükség szerint három-négy óránként ismételve) kellő mértékű fájdalomcsillapító hatást értünk el, mégsem tudtuk általánosan alkalmazni. Ennek hátterében a kábító fájdalomcsillapító adásától való ódzkodás, a mellékhatásoktól (hányinger, hányás, erôs fejfájás, légzésdepresszió) való félelem állhatott. A gyakorlati kivitelezés is akadályokba ütközött: osztályunkon készenléti ügyeleti szolgálat müködik, s az ügyeletes orvos távollétében a morfinkészítmény beadása nem engedélyezett.

- Az utóbbi években általánossá vált az epiduralis katéter alkalmazása, amely lehetőséget biztosít a mütét utáni 24-48 órában a katéteren keresztül hatóránként bolusban vagy infúziós pumpával folyamatosan anesztetikum adására, amellyel teljes fájdalommentesség érhető el. A módszer hátránya a megvalósíthatóságában és annak időzítésében rejlik. Szükséges az aneszteziológus jelenléte az osztályon a hatóanyag beadásakor, mégpedig akkor, amikor a betegnek még nincsenek fájdalmai. Ennek hiánya esetén hiába a kiváló módszer, gyakran meghiúsul az alkalmazása.

- Kiváló, mútét utáni fájdalomcsillapítás érhető el ultrahangvezérelt perifériás idegblokád alkalmazásával. A kanülön keresztül adagolható lokálanesztetikumokkal szükség szerint 24-48-72 órás fájdalommentesség biztosítható, de gyakori mellékhatás az átmeneti izomgyengeség, amely alsó végtagi alkalmazás esetén a betegek korai mobilizációját akadályozhatja. Jelen tanulmány készítésekor ez az eljárás számunkra még nem volt a mindennapi gyakorlatban elérhető.

$\mathrm{Az}$ intraoperatív lokális infiltrációs analgesia (LIA) csak az utóbbi tíz évben terjedt el az angolszász területeken [2]. Lényege, hogy a mütéti terület valamennyi rétegét (legmélyebbtől a felületesig) a mütét adott stádiumaiban egy előre meghatározott recept szerint összeállított oldattal fecskendezik be. A koktél hosszú felezési idejű lokálanalgetikumot, továbbá adrenalint és nem szteroid típusú gyulladáscsökkentőt tartalmaz, nagy volumenre (150 ml) felhígítva. Az infiltrálást követően 12-18 órás fájdalomcsillapító-fájdalomcsökkentő hatás érhető el. Több szerző számolt be egyéb adalékok (morfin, szteroid típusú gyulladáscsökkentő, antibiotikum) hozzáadásával szerzett tapasztalatokról is [2-4].

Az eljárás népszerúsége a nemzetközi közlemények száma alapján igen nagy, hazánkban is voltak próbálkozások $[5,6]$. Ennek ellenére a módszert Magyarországon széles körben nem alkalmazzák, hazai közlemény mind ez idáig nem jelent meg a témában. Ennek oka feltehetően az eljárás költséges mivoltában rejlik.

A Markusovszky Egyetemi Oktatókórház Ortopédiai Sebészeti Osztályán 2015 júniusában alkalmaztuk először az intraoperatív helyi infiltrációs érzéstelenítést. A kezdeti jó tapasztalatok után valamennyi nagyízületi endoprotetikai műtétnél rutinszerüen kezdtük alkalmazni. Költséghatékonysági megfontolásból azonban kénytelenek voltunk módosítani az eredeti recepten.

Jelen közlemény célja, hogy felmérjük, milyen hatással van a betegek mútét utáni fájdalmára a magunk által módosított recept szerint összeállított helyi infiltrációs analgetikum a primer csípő- és térdízületi teljes protézisbeültetésen átesett betegek közvetlen posztoperatív fájdalmára.

\section{Módszer}

2015. augusztus és 2015. december között primer csípő-, illetve térdízületi totális endoprotézis-beültetésen átesett 99 páciens adatait dolgoztuk fel prospektíve. Kiválasztásuk időben egymás utáni sorrendiségben történt. Valamennyi páciens a mütét során helyi infiltrációs érzéstelenítésben részesült. $10 \mathrm{ml}$ Naropin $10 \mathrm{mg} / \mathrm{ml}$ (AstraZeneca) oldatot kevertünk $10 \mathrm{ml}$ Lidocain-Adrenalin 20 $\mathrm{mg} / 0,01 \mathrm{mg} / \mathrm{ml}$ (Egis) oldattal, amelyet végül $130 \mathrm{ml}$ $\mathrm{NaCl} 0,9 \%$ oldattal hígítottunk fel (az összetevők menynyisége testtömegtől független, egységesen alkalmazott). Az így kapott összesen $150 \mathrm{ml}$ oldatot $50 \mathrm{ml}$-es részletekben infiltráltuk a műtéti terület mély és felületes rétegeibe: csípőprotézis beültetése során az első $50 \mathrm{ml}-\mathrm{t}$ az acetabulum köré 360 fokban, a második $50 \mathrm{ml}$-t a protézis beültetését követően az abductor izomhasba, a vastus lateralis eredéséhez és a fascia lata területére. A harmadik $50 \mathrm{ml}$-t a bőr alatti zsírrétegbe. Térdprotézis esetében az első adagot a hátsó ízületi tokba, az oldalszalagok területére és a hátsó keresztszalagba (ha hátsó ke- 
resztszalagot megtartó implantátumot ültettünk be), a második adagot a suprapatellaris recessus falába és a vastusizomzat térdhez közeli részébe, továbbá az ízületi tokba, a harmadik dózist itt is a bőr alatti zsírszövetbe.

$\mathrm{Az}$ adatgyújtés során táblázatos formában rögzítettük a betegek nemét, életkorát a mútét időpontjában, a mütéti anesztézia típusát:

- általános anesztézia;

- spinalis subarachnoidealis anesztézia;

- spinalis epiduralis anesztézia (kombináltan subarachnoidealis anesztéziával vagy a nélkül).

A beavatkozás mibenlétét is leírtuk:

- cementes totális csípőendoprotézis-beültetés;

- cement nélküli totális csípőendoprotézis-beültetés;

- totális térdprotézis-beültetés (jelen gyakorlatunkban ez mindig cementes rögzítéssel történik).

A posztoperatív időszakban óránként feljegyeztük, hogy a 0-10-ig terjedő numerikus skálán a beteg milyen fájdalomerősséget jelölt meg, szóbeli közlés alapján $(0=$ egyáltalán nem érez fájdalmat, $10=$ elviselhetetlenül erős fájdalmat érez). A táblázatban rögzítettük az alkalmazott intravénás, per os vagy EDA-kanülön keresztül adott fájdalomcsillapítók beadásának idejét, az alkalmazott gyógyszer nevét és dózisát.

A vizsgálatból való kizáró oknak számított a helyi infiltrációs analgetikum bármely alkotórészével szembeni ismert túlérzékenység.

Kontrollcsoportként egy korábban megkezdett, szintén a mütét utáni fájdalomcsillapítás effektusát felmérni hivatott vizsgálatba bevont, 2013 szeptembere és 2014 márciusa között 85, továbbá 2014 szeptembere folyamán operált 12, összesen 97 teljes primer csípő-, illetve térdprotézis-beültetésen átesett páciens szolgált. Adataikat szintén prospektív módon rögzítettük, kiválasztásuk időben egymás utáni sorrendiségben történt. (2014 áp-

1. táblázat |A betegek megoszlása a vizsgálati és a kontrollcsoportban

\begin{tabular}{llll}
\hline & Betegek száma & Nő/férfi & Életkor (év) \\
\hline LIA & 99 & $59 / 40$ & $68(41-84)$ \\
Non-LIA & 97 & $55 / 42$ & $66(51-86)$ \\
\hline
\end{tabular}

LIA = lokális infiltrációs analgetikum adásában részesült betegek; non-LIA = lokális infiltrációs analgetikum adásában nem részesült betegek - kontrollcsoport rilisa és augusztusa között adminisztratív hibából nem történt a fájdalomra vonatkozó adatrögzítés egyetlen operált betegnél sem.)

Az így kapott adatok alapján összefüggést kerestünk a mútét utáni fájdalom erôssége, a mütét utáni fájdalomcsillapító-igény és azon tény között, hogy a mütét során a beteg részesült-e helyi infiltrációs érzéstelenítésben. Költségelemzést végeztünk, vajon a helyi infiltrációs érzéstelenítés milyen többletköltséggel, esetleg költségmegtakarítással jár-e.

\section{Eredmények}

A vizsgálati és a kontrollcsoport adatait az 1. és 2. táblázat szemlélteti. Vonalas grafikonon szemléltetjük a betegek által megjelölt fájdalomszintet a mútét utáni első 18 órában (1. és 2. ábra).

Összevetettük egymással a térd- és csípőprotézis-beültetésen átesett betegek fájdalomérzetét. Az így kapott adatokat a 3. és 4. ábra vonalas grafikonjai demonstrálják.

A mútét utáni fájdalomcsillapító-igényt mutatja be az 5. ábra.

A statisztikai számítások során átlagoltuk minden egyes betegnek a mútét után óránként jelzett fájdalomértékeit. Az így kapott átlagértékeket kétmintás Studentféle t-próbával elemeztük. A vizsgálati csoportban a mútét utáni első 18 órában az átlagos fájdalomérzet szignifikánsan alacsonyabb volt $(\mathrm{p}<0,001)$. Átlagoltuk a fájdalomértékeket a mütét után eltelt idő függvényében is, azaz a mútét után eltelt minden egyes órában valamennyi beteg által jelzett fájdalomértéket adtuk össze és osztottuk a betegek számával. Az így kapott értékek alapján is a vizsgálati csoportban szignifikánsan alacsonyabb volt a fájdalom $(\mathrm{p}<0,001)$.

A csípő-, illetve térdmútéten átesett betegek csoportját egymással összehasonlítva nem találtunk szignifikáns különbséget a mưtét utáni első 18 óra során jelzett fájdalomértékek között (3. ábra). Csak és kizárólag az infiltrációs analgesiában nem részesült - azaz a hagyományos fájdalomcsillapítással ellátott - csípő-, illetve térdízületi teljes endoprotézis-beültetésen átesett betegek fájdalomérzete között kaptunk statisztikailag szignifikáns különbséget (4. ábra), de akkor is csak a mütét utáni első ötórás időtartamban $(\mathrm{p}=0,02)$.

2. táblázat |A betegek megoszlása a vizsgálati és a kontrollcsoportban

\begin{tabular}{llll|l|lc}
\hline & \multicolumn{2}{l|}{ Mútét típusa } & & Oldaliság & Anesztézia típusa \\
\cline { 2 - 7 } & $\begin{array}{l}\text { Cementes } \\
\text { csípö-TEP }\end{array}$ & $\begin{array}{l}\text { Cement nélküli } \\
\text { csípö-TEP }\end{array}$ & Térd-TEP & (bal/jobb) & Általános & Spinal \\
\hline LIA & 29 & 30 & 40 & $49 / 50$ & 39 & 51 \\
Non-LIA & 31 & 24 & 42 & $50 / 47$ & 47 & 36
\end{tabular}

LIA = lokális infiltrációs analgetikum adásában részesült betegek; non-LIA = lokális infiltrációs analgetikum adásában nem részesült betegek - kontrollcsoport; TEP = totális endoprotézis 


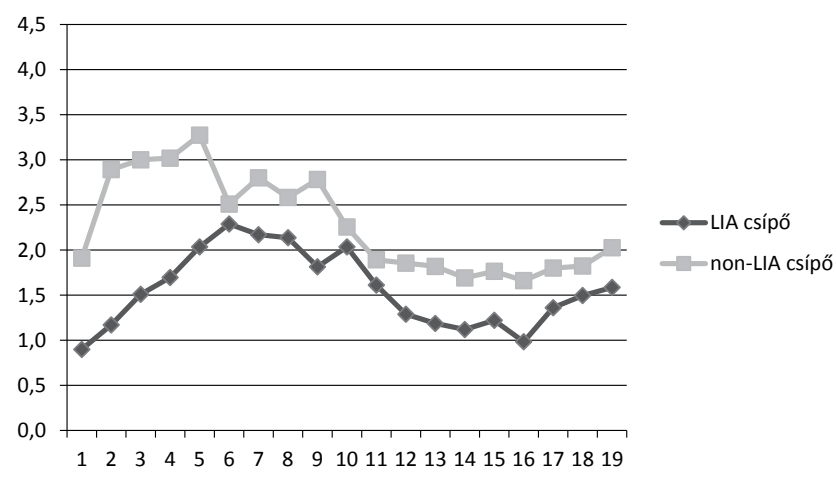

1. ábra

A fájdalomérzet alakulása a mútét utáni szakban csípơízületi endoprotézis-beültetésen átesett betegeknél

LIA = infiltrációs analgesiában részesült betegek csoportja; non LIA $=$ kontrollcsoport
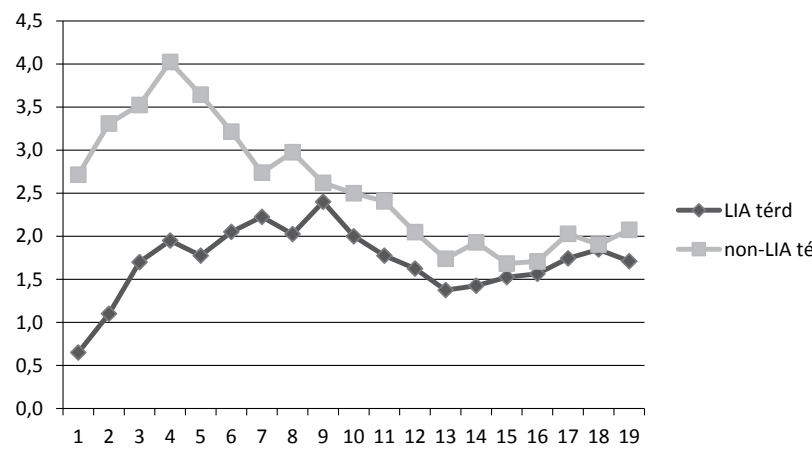

2. ábra

$\begin{aligned} & \text { A fájdalomérzet alakulása a mútét utáni szakban térdízületi en- } \\ & \text { doprotézis-beültetésen átesett betegeknél }\end{aligned}$
LIA = infiltrációs analgesiában részesült betegek csoportja; non-
LIA = kontrollcsoport

A költséganalízis eredménye szerint az egy före jutó mútét utáni fájdalomcsillapító gyógyszerre fordított öszszeg a vizsgálati csoportban: $368 \mathrm{Ft}$, ugyanez a kontrollcsoportban: $689 \mathrm{Ft}$. A különbség szignifikáns $(\mathrm{p}<0,001)$. A lokális infiltrációs koktél ára (amely a vizsgálati csoport költségeit növeli) fejenként 2223 Ft.

\section{Megbeszélés}

A nem megfelelően végzett posztoperatív fájdalomcsillapítás számos rövid és hosszú távú kedvezőtlen következménnyel járhat, mint például krónikus fájdalomszindróma, elhúzódó posztoperatív morbiditás, csökkent életminőség [7].

A csípő- és térdízületi totális endoprotézis-beültetések a leggyakrabban végzett felnőtt ortopédiai beavatkozások. Egy nagyízület megnyitása mindig komoly posztoperatív morbiditással járt. Ezt mérsékelendő és a korai eredményes rehabilitáció reményében dolgozták ki a minimálisan, illetve a minimalizált invazív technikákat: csökkentett szöveti traumatizáció elvileg kisebb posztoperatív fájdalmat von maga után. A módszer hátránya, hogy nem minden esetben alkalmazható: a beteg anató-

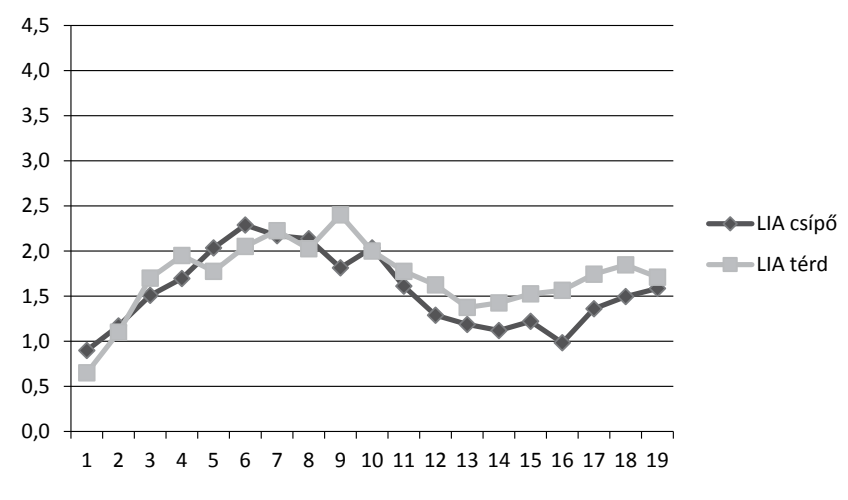

3. ábra $\quad$ Infiltrációs analgesia alkalmazása esetén nincs szignifikáns különbség a közvetlen mútét utáni szakban a térd-, illetve csípőízületi mútéten átesett betegek fájdalomérzete között

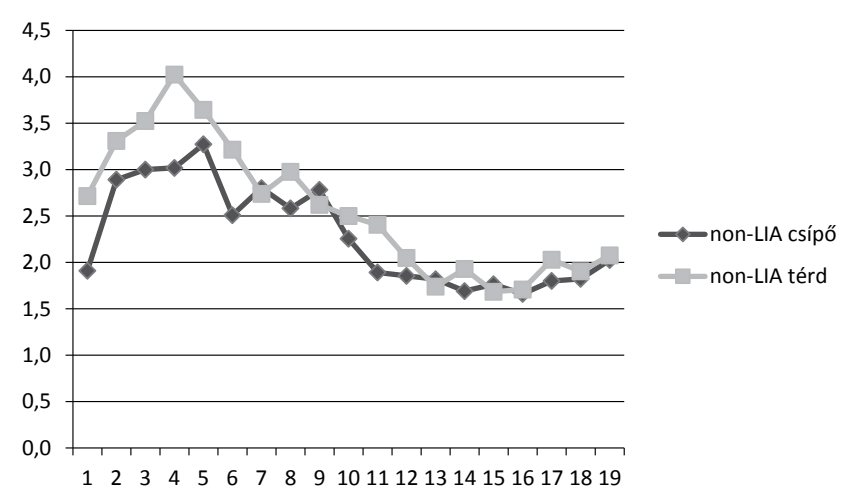

4. ábra

Hagyományos fájdalomcsillapítás alkalmazásakor szignifikáns a különbség az első öt órában regisztrált fájdalomerősség tekintetében térd-, illetve csípőízületi teljes endoprotézis-beültetésen átesett betegek csoportja között

miai adottságai, az elváltozás típusa, súlyossága, intraoperatív komplikációk fellépte, az operatór gyakorlottsága, a rendelkezésre álló eszközök típusa mind-mind olyan tényezők, amelyek akár meg is hiúsíthatják a minimálisan invazív mütét kivitelezhetőségét.

Korábban azt tapasztaltuk, hogy a leghatásosabb mưtét utáni fájdalomcsillapítást az alsó végtag esetében az

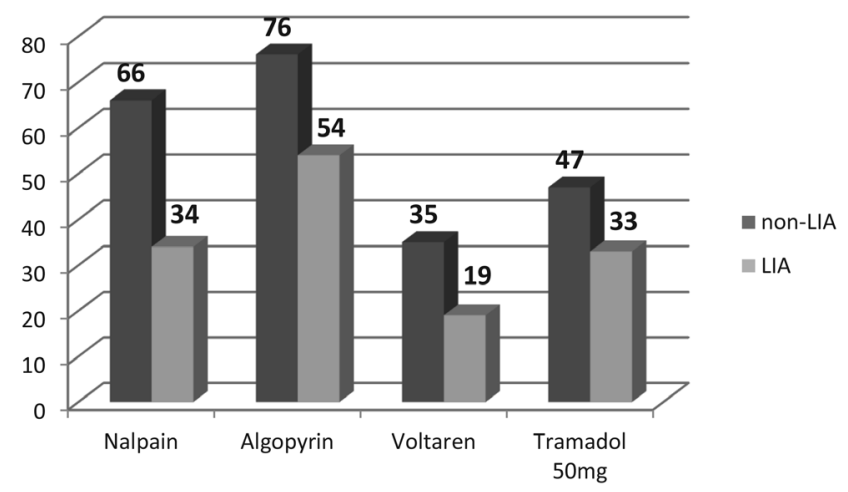

5. ábra $\quad$ Fájdalomcsillapító igény a vizsgálati és a kontrollcsoportban a műtét utáni első 18 óra folyamán (a feltüntetett számok a beadott ampullák mennyiségét jelzik) 
epiduralis kanülön át folyamatosan, infúziós pumpával vagy PCA-pumpával adagolva lehet elérni. Elektív ortopédiai mütétre kerülő betegeknél ellenjavallata gyakorlatilag nincs (leszámítva a hatóanyaggal szembeni ismert túlérzékenységet), kivitelezhetôségének inkább technikai akadályai lehetnek (súlyos degeneratív lumbalis gerincbetegség, extrém kövérség). Ügyeleti időben az aneszteziológusok folyamatos sürgősségi jellegű foglalkoztatottsága gyakran nem teszi lehetővé számukra, hogy az aznap operált betegeket többszöri alkalommal is felkeressék, az epiduralis kanül funkcióját ellenőrizzék, abba akár bolusban, akár az infúziós pumpán keresztül ismételten hatóanyagot adhassanak be.

A szakirodalomban foglaltak szerint a helyi infiltrációs analgesia nemcsak eredményes fájdalomcsillapító módszer, hanem biztonságos is [8]. Az utóbbi évek tapasztalata szerint hatékonyabb az epiduralis fájdalomcsillapításnál is $[9,10]$. A tartós hatást egyrészt a hosszú felezési idejű ropivacain biztosítja, másrészt a hozzáadott adrenalin kiváltotta helyi vasoconstrictio lassítja a hatóanyagnak a vérárammal való elillanását. A ropivacain további előnye, hogy cardiotoxicitása az összes tartós hatású lokálanesztetikum közül a legalacsonyabb. A recept szerint $30 \mathrm{ml} \mathrm{1 \% -os} \mathrm{ropivacain} \mathrm{az} \mathrm{ajánlás,} \mathrm{továbbá} 0,5$ mg adrenalint és 1 ampulla ketorolacot tartalmaz a beadott koktél [2]. Ez utóbbi nem szteroid gyulladáscsökkentőnek jó adjuváns fájdalomcsillapító hatást tulajdonítanak [3].

Gupta és mtsai további jó fájdalomcsillapító hatásról számoltak be a mütéti területbe behelyezett katéteren keresztül beadott további lokálanesztetikum alkalmazásával [11]. Más szerzők nem találtak különbséget a sebbe helyezett kanül alkalmazásával, de felhívják a figyelmet a posztoperatív sebfertőzés veszélyére [12].

Saját gyakorlatunkban, elsősorban költségtakarékossági megfontolásból, valamint azért, mert Magyarországon a ketorolac nem törzskönyvezett, változtattunk az infiltrációs koktél összetevőin: a ropivacain $\left(\right.$ Naropin $\left.^{\circledR}\right)$ dózisát harmadára csökkentettük, a hiányzó mennyiséget, valamint az adrenalint tonogénes Lidocainnal pótoltuk. Nem szteroid gyulladáscsökkentő helyi adásától pedig eltekintettünk, azt protokoll szerint az aneszteziológusok parenteralisan adják az ortopédiai nagymútéten átesett betegeknek. Az ebbe a csoportba tartozó, hazánkban elérhető injekciós készítmények alkalmazási elöirata szerint csak intramuscularisan adagolhatók, illetve az egyik legelterjedtebben használt készítmény esetében pedig kifejezetten kerülendő más hatóanyagokkal való keverése.

Az adrenalin alkalmazásával kapcsolatban meg kell jegyeznünk, hogy az általunk alkalmazott oldat mindössze 100 mikrogramm hatóanyagot tartalmaz. Ez időben és a térben is három részre elosztva kerül beadása, összesen $150 \mathrm{ml}$ oldatban. A nemzetközi gyakorlatban adrenalinból a fenti mennyiség 4-5-szörösét is beadják, de sem tenziókiugrásról, sem bőrnekrózisról nem tesznek említést a témával foglalkozó szerzők [2-4, 8-10]. Nagyízületi endoprotézis-beültetés céljából csak jól beállított, stabil vérnyomásértékekkel kerülhet a beteg mútőasztalra. Magunk egyetlen esetben sem tapasztaltunk vérnyomás-emelkedést a koktél beadását követően. Mindemellett a fokozott elővigyázatot célszerünek tartjuk, különösen akkor, ha a betegnek az intraoperatív tenzióértékei a vártnál magasabbak lennének. Ami a bőrnekrózist illeti, az adrenalin nagyfokú hígítása miatt nem kell tartani ettől a szövődménytől sem. A csípő régiójában a bőr alatti zsírszövet kellően vastag, biztonságosan el lehet végezni a felületes infiltrációt is. A térd esetében vékony testalkatú betegeknél a patella szintjében és az alatt a subcutan réteg igen vékony lehet. Ennek ellenére itt is elvégeztük a subcutan infiltrációt, szövődményre utaló jelet egyetlen esetben sem észleltünk.

A költségeket figyelembe véve, az összetevôk közül a ropivacain a legdrágább, ampullája $2100 \mathrm{Ft}$ körüli áron kapható (Naropin ${ }^{\circledR} 1 \% 10 \mathrm{ml}$, AstraZeneca), a szükséges adrenalin további $2500 \mathrm{Ft}-\mathrm{os}$ terhet jelent. Ha az eredeti recept mellett maradunk, az havonta $270000 \mathrm{Ft}$ többletköltséget rótt volna az osztályos gyógyszerkeretre, átlagosan havi 30 ily módon kezelt beteggel számolva. A koktél összetevőinek módosításával a költséget sikerült egynegyedére csökkentenünk, amihez további költségcsökkentő tényezőként járul hozzá az infiltrált betegek kimutatott alacsonyabb fájdalomcsillapító-igénye a műtét utáni szakban. Ez nemcsak a be nem adott ampullák számában jelent megtakarítást, hanem a beadáshoz használt tü és fecskendő mennyiségében, továbbá a nővéri munkavégzés, ráfordított idő és adminisztráció tekintetében is.

Mint korábban hangsúlyoztuk, a koktél összetételének módosítására kizárólag a költségek csökkentése ösztönzött bennünket. Hasonló módon változtatott összetételû oldattal történő infiltrációs fájdalomcsillapításról szóló közleménnyel a szakirodalom áttekintése során nem találkoztunk.

A vizsgálati csoport betegeinek kevesebb, a kontrollcsoport betegeinek lényegesen több fájdalomcsillapítót adtunk a mútét utáni első 18 órában. Szignifikáns különbséget ugyan nem sikerült kimutatnunk $(\mathrm{p}=0,15)$, de a 4. ábra egyértelmúen mutatja a jó irányú tendenciát.

A kontrollcsoport betegei által kapott nagyobb menynyiségű fájdalomcsillapító gyógyszerek hatásának köszönhető az is, hogy az 1-3. ábrákon látható fájdalomgörbék kisebb (de még így is szignifikáns: $\mathrm{p}<0,001$ ) különbséget mutatnak a betegek fájdalomérzetét tekintve, mint ahogy azt saját szubjektív megítélésünk alapján vártuk. Véleményünk szerint az igazi különbség akkor jelent volna meg, ha mindkét csoport betegei ugyanolyan mütét utáni fájdalomcsillapító-adagolásban része- 
sültek volna, ezt azonban nyilvánvaló etikai okokból nem tartottuk kivitelezhetönek.

$\mathrm{Az}$ eredményes fájdalomcsillapítás további hozama, hogy azok a betegek, akik a közvetlen posztoperatív szakban nem éltek át nagyfokú mútéti fájdalmat, azok már a mútét napján elkezdik mozgatni operált végtagjukat, s a továbbiakban is bátrabbak a mobilizáció során, rehabilitációjuk könnyebb, gyorsabb, aktív osztályos ápolási idejük lerövidül. A mútét után két nappal már önellátóvá válnak, általában nem szorulnak nővéri segítségre sem a tisztálkodás során, sem alapvető szükségleteik kielégítése terén.

A fájdalomnak élettani szerepe, hogy kíméli a mechanikus eredetú károsító behatásoktól a sérült szöveteket, biztosítja a regenerációhoz szükséges nyugalmat. A fájdalom kikapcsolása esetén ennek a védekezőmechanizmusnak a hiányában teoretikusan elképzelhető, hogy a frissen operált betegek nem kellő óvatossággal bánnak saját operált végtagjukkal. Osztályunk gyakorlatában a fájdalommentességhez köthető, szövődményhez vezető kooperációs probléma (operált végtag túlterhelése, túlmozgatása, nem engedélyezett felkelés, eséses trauma) nem fordult elő.

\section{Következtetés}

Eredményeink alapján az általunk módosított összetételü lokális infiltrációs analgesiát hatékony, megbízható, könnyen alkalmazható, gazdaságos módszernek tartjuk, amelyet bátran ajánlunk a nagyízületi endoprotézis-beültetést végző kollégáknak, hogy operált pácienseik számára elviselhetővé tegyék a műtét utáni első időszakot.

Anyagi támogatás: A közlemény megírása, illetve a kapcsolódó kutatómunka anyagi támogatásban nem részesült.

Szerzői munkamegosztás: de J. T.: A vizsgálat megszervezése, koordinálása, a végleges szöveg megfogalmazása. G. Sz.: Adatgyưjités, ábrák, táblázatok elkészítése. Sz. G.: Adatgyüjtés, számítások. T. M. B.: Adatgyưjtés, a szakirodalom áttekintése. A cikk végleges változatát valamennyi szerző elolvasta és jóváhagyta.

Érdekeltségek: A szerzőknek nincsenek érdekeltségeik.

\section{Irodalom}

[1] De Jonge, T.: Pharmacological reduction of bleeding during hip endoprosthetic replacement. [Gyógyszeres vérzéscsillapítás csípőízületi endoprotézis-beültetések során.] Orv. Hetil., 2012, 153(41), 1607-1612. [Hungarian]

[2] Busch, C. A., Shore, B. J., Bhandari, R., et al.: Efficacy of periarticular multimodal drug injection in total knee arthroplasty. A randomized trial. J. Bone Joint Surg. Am., 2006, 88(5), 959963.

[3] Kerr, D. R., Kohan, L.: Local infiltration analgesia: a technique for the control of acute postoperative pain following knee and hip surgery: a case study of 325 patients. Acta Orthop., 2008, $79(2), 174-183$.

[4] Maheshwari, A. V., Blum, Y. C., Shekhar, L., et al.: Multimodal pain management after total hip and knee arthroplasty at the Ranawat Orthopaedic Center. Clin. Orthop. Relat. Res., 2009, 467(6), 1418-1423

[5] Kovács, Gy., Janositz, G.: LIA: Local Infiltration Analgesia - Early experience in twenty knee replacement surgeries. Joint Congress of the Hungarian Orthopaedic Association and Hungarian Society for Traumatology, Pécs, 2010. [LIA „Lokális Infiltrációs Analgézia" - kezdeti tapasztalatunk húsz térdprotézis beültetése kapcsán. A Magyar Ortopéd Társaság és a Magyar Traumatológus Társaság Közös Kongresszusa, Pécs, 2010.] [Hungarian]

[6] Vámbidy, L. 2009. Personal communication [személyes konzultáció].

[7] Liu, S., Carpenter, R. L., Neal, J. M.: Epidural anesthesia and analgesia - their role in postoperative outcome. Anesthesiology, $1995,82(6), 1474-1506$.

[8] Röstlund, T., Keblet, H.: High-dose local infiltration analgesia after hip and knee replacement: what is it, why does it work, and what are the future challenges? Acta Orthop., 2007, 78(2), 159161.

[9] Tsukada, S., Wakui, M., Hoshino, A.: Postoperative epidural analgesia compared with intraoperative periarticular injection for pain control following total knee arthroplasty under spinal anesthesia. A randomized controlled trial. J. Bone Joint Surg. Am., 2014, 96(17), 1433-1438.

[10] Hu, B., Lin, T., Yan, S. G., et al.: Local infiltration analgesia versus regional blockade for postoperative analgesia in total kness arthroplasty. A meta-analysis of randomized controlled trials. Pain Phys. J., 2016, 19(4), 205-214.

[11] Gupta, A., Favaios, S., Perniola, A., et al.: A meta-analysis of the efficacy of wound catheters for post-operative pain management. Acta Anaesthesiol. Scand., 2011, 55(7), 785-796.

[12] Reeves, M., Skinner, M. W.: Continuous intra-articular infusion of ropivacaine after unilateral total knee arthroplasty. Anaesth. Intensive Care, 2009, 37(6), 918-922.

(de Jonge Tamás dr., Szombathely, Markusovszky u. 5., 9700 e-mail: dejonget@hotmail.com)

\section{Affirmanti incumbit probatio. (Aki állít valamit, annak feladata a bizonyítás.)}

